\title{
Course Design of Indonesian Language for Foreign Speakers in Vocational Education
}

\author{
Degita Danur Suharsono* \\ Bahasa, Komunikasi, dan Pariwisata \\ Politeknik Negeri Jember \\ Jember,Indonesia \\ danur@polije.ac.id \\ ORCID: 0000-0001-6276-9489
}

\author{
Julien Arief Wicaksono \\ Bahasa, Komunikasi, dan Pariwisata \\ Politeknik Negeri Jember \\ Jember,Indonesia \\ julien_arief@polije.ac.id \\ ORCID: 0000-0002-1092-2442
}

\author{
Gullit Tornado Taufan \\ Bahasa, Komunikasi, dan Pariwisata \\ Politeknik Negeri Jember \\ Jember,Indonesia \\ gullittaufan@polije.ac.id \\ ORCID: 0000-0003-0896-0738
}

\begin{abstract}
This research was initiated from the problem of how to design the course in teaching Bahasa Indonesia (Indonesian Language) for foreign speakers (BIPA) which is relevant and suitable to be used in vocational education. The vocational education system is a combination of knowledge, skills, and ethics. In vocational education, more than half of learning activity focuses on practicum activity. The purpose of this study is to describe the design of BIPA's course materials in vocational education. The qualitative design is the basic reference for the research method in this study. To accommodate this method, this study used three data collection techniques, namely interviews, observation, and documentation. The data collection instruments used in this study were interview guides, observation guidelines, and documentation check list. The results of data collection were then analyzed and processed to produce BIPA's course designs in vocational education. The course design includes the design for developing BIPA's course materials, the design of BIPA's learning objectives, and the design of procedures for the preparation of BIPA course materials. This course design is expected to be used as a guideline and reference for the developing BIPA's course materials in vocational education.
\end{abstract}

Keywords - course design, BIPA, vocational education

\section{INTRODUCTION}

Bahasa Indonesia (Indonesian Language) for Foreign Speakers, known as BIPA, plays a pivotal role as the medium to promote both Bahasa Indonesia and Indonesian culture all around the globe. BIPA is a program designed specifically for foreigners. The program is not only administered in Indonesia but also in various countries that have diplomatic affairs with Indonesia. According to Badan Pengembangan dan Pembinaan Bahasa, there are 471 institutions providing BIPA program in 30 countries [1].

Historically, BIPA has been introduced prior to the independence of Indonesia. As explained by Suyitno [2], Bahasa Indonesia has been learned in Japan since 1925, in the USA since 1948, in China since 1950, in Australia since 1957, in Italy since 1964, in South Korea since 1964, in England since 1967, in New Zealand since 1968, and other countries both in Europe and Asia. In Indonesia, BIPA started its journey officially in 1972 [2].

Unfortunately, BIPA teaching and learning, so far, do not have any conceptual framework as a reference regarding the materials, methods, and any other aspects related to the teaching and learning process. Therefore, the researchers believe that the effort to develop references for BIPA teaching and learning should be made continuously. This is essential in order to broaden the insights into how BIPA teaching and learning should be ideally conducted either in general or specific contexts, including in vocational universities.

The main objective of vocational university is to equip the students with skills and knowledge to enter the professional world. It means that vocational university has a strategic role to educate and train the students to learn and master knowledge, skills, as well as good personality. Those will help the students to be skillful professionals not only in industrial and formal sectors but also as enterpreneurs [3]. The curriculum of vocational university is developed based on several aspects including teaching and learning needs, the demands in work places, IT development, and global challenges. The teaching and learning process is administered by considering three aspects including knowledge, skills, and personality. The emphasize is in practice that covers $60-70 \%$ with only around $30-40 \%$ theories. This applies to any courses taught.

This study aimed at describing the design of BIPA learning materials in vocational context. The design accommodated the development of learning materials, the objectives of teaching and learning process, and the procedures in developing the learning materials.

\section{METHOD}

This is a descriptive qualitative research that describes the design of BIPA learning materials in vocational education covering the design of BIPA learning materials in vocational context. The design accommodated the development of learning materials, the objectives of teaching and learning process, and the procedures in developing the learning materials. The study was conducted at Politeknik Negeri Jember from June to August 2020.

The data was collected from BIPA teachers, practitioners, and learners, as well as related documents and literatures. The researchers themselves were the main instrument who got involved in the data collection and analysis. Besides, the researchers also employed interview, observation, and documentation to collect the supporting data.

Through the interview, the researchers collected the data regarding how BIPA teaching and learning activities were 
done. In order to capture the distinction between the real condition and ideal concept of BIPA teaching and learning process, the researchers conducted an observation. Furthermore, the documentation was done to study the regulation, policy, and current literatures related to BIPA. In addition, triangulation was used to test the validity of the data and data collection techniques.

There were two steps of the data analysis including the data analysis while the researchers were collecting the data and the analysis after the data was collected completely. The first step was done to decide what data to collect, eliminate irrelevant data, and check the validity. The data analysis that took place after the data collection was done to examine, classify, test, present, and interpret the research data.

\section{DISCUSSION}

The BIPA learning material development in vocational universities should be standardized. Standardization is needed to make sure that the materials given to BIPA learners, especially at vocational university, are appropriate with learners' levels of education. The BIPA learning materials are developed both in forms of printed and audiovisual materials to make sure that they are easy to access and use. In addition, it is also important to consider Indonesian local cultures as the part of the materials. Regarding current study, the BIPA learning material is developed by referring to regulation by Badan Pengembangan dan pembinaan Bahasa, the assistance from BIPA teachers, and the supervision of UPT Bahasa (Language Center) of Politeknik Negeri Jember as the administrator of BIPA.

Competence is an aspect that needs to be taken into account when developing BIPA learning material. According to the Department of National Education [4], the development of learning materials should consider the completeness of the competencies that the learners have to learn and master. Each competence has its own characteristics regarding the materials given in the learning process. Therefore, it is important to carefully identify the objectives of BIPA learning in vocational context in order to appropriately develop the materials that the learners need according to the standard of competence and basic competence that covers cognitive, psychomotoric, and affective domains.

The development of BIPA learning material can refer to Bloom's taxonomy covering cognitive, psychomotoric, and affective domains [5]. Regarding the cognitive domain, specifically, the development of BIPA learning material in vocational context can be based on Fink's taxonomy, a constructivism taxonomy, that emphasizes in constructing knowledge of BIPA learners at vocational university [6]. Fink divides the taxonomy into six dimensions including knowledge, implementation, integration, humanity, care, and long life learning.

For the psychomotoric domain, the development of the learning material can be based on Bixler's taxonomy that combines Dave's, Simpson's, and Harrow's taxonomies. Bixler's taxonomy is appropriate to equip learners with the skills they need including listening, speaking, reading, and writing [7]. Bixler divides the taxonomy into four dimensions covering observing, imitating, practicing, and adapting.

Regarding the affective domain, the BIPA learning material can be developed based on Krathwohl's taxonomy.
This emphasizes in promoting learners' positive and appreciative attitude towards Indonesian culture. Murray divides Krathwohl's taxonomy into five dimensions including accepting, answering, appreciating, organizing, and doing [5].

Based on the three domains explained regarding the BIPA learning material development, the objectives of BIPA in vocational context can be determined. There are two main objectives of BIPA in vocational context: teaching Bahasa Indonesia and introducing Indonesia's cultures to foreign learners. The objectives should be stated in the syllabus. More importantly, the objectives of BIPA should be based on the regulation of the Ministry of Education and Culture of Indonesian Republic Number 27, 2017 about the Graduates' Standard Competence of BIPA Course and Training.

Based on the regulation, the objectives of BIPA learning material may be based on the Common European Framework of Reference (CEFR) for language model and graded under the Uji Kemahiran Berbahasa Indonesia (UKBI), the test of Bahasa Indonesia proficiency. The CEFR can be used as a reference because Bahasa Indonesia itself, in the context of BIPA, is a foreign language for its leaners. It means that CEFR is relevant to be a reference of determining the objectives of BIPA. In addition to the testing system, UKBI has been standardized by Badan Pengembangan dan Pembinaan Bahasa to test the proficiency of Bahasa Indonesia both for Indonesians and foreigners.

The objectives BIPA teaching and learning activities at a vocational university can be integrated in the syllabus. One of the recommended models of the syllabus of BIPA at a vocational university is the mixed model which combines national syllabus and task-based syllabus [8]. In this case, the sources should meet certain qualifications covering (1) motivating learners to learn, (2) based on the principles of learning to write, (3) having good objectives, (4) suitable for the condition of learning environment. The objectives of BIPA learning should meet the learners' needs, characteristics, and the development of science and technology.

The development of the objectives of BIPA learning at vocational university is arranged based on teaching and learning foundation. The foundation of BIPA learning at a vocational university can be divided into two: juridical and empirical. The juridical foundation of BIPA learning refers to the regulation of the Ministry of Education and Culture of Indonesian Republic Number 27, 2017 while the empirical foundation is based on the theoretical reviews and preliminary study.

The objectives of BIPA learning at vocational context can be based on Competency-Based Language Teaching (CLBT). CLBT is related to the process that emphasizes in development of material [9]. In this case, the development of the objectives of BIPA learning, which is based on CLBT, accommodates learners' levels of education, characteristics, and needs.

\section{A. The Procedure of Developing BIPA Learning Materials}

The development of BIPA learning materials comprises four aspects, i.e. (1) the objective of the material development, (2) the principle of material development, (3) the procedure of material development, and (4) the advantage of material development. The objective of material development is to 
fullfil the needs of BIPA teaching and learning. Regarding the principle, it is important to remember that this is the fondation of the teaching and learning process. Therefore, it is also essential to take into account the procedure of developing the materials covering certain levels in the process of BIPA material development. As a result, the advantages of the material development, that will positively contribute to academic achievement can be realized. The following elaborates more about the aspects.

There are three objectives of material development. Those are (1) to effective and efficient teaching and learning, (2) to improve BIPA learners' proficiency, and (3) to promote Indonesian culture. Besides, the Department of National Education (2008) also states that the objectives of material development are (1) to explain the real process of teaching and learning, (2) to cope the limitation of time, space, and learning materials during the teaching and learning process, and (3) to be used as the learning material in effective, efficient, and varied.

The procedure of material development is employed to ensure that the validity of the teaching and learning materials. Therefore, the material development refers to the procedure. Akbar states that there are four steps in developing materials [10]. They are (1) identifying problems, (2) analyzing curriculum, (3) drafting the learning material, and (4) revising the draft. In the first step, identifying problems, the researchers reviewed current sources of learning materials and handbooks, reviewed theories, observed, and analyzed related documents. Next, the researchers analyzed the existing curriculum to analyze the standard of competence, basic competence, and to formulate indicators and teaching objectives. Then, the researchers came to the next step; drafting the learning material and validate it. As the final step, the researchers then revise the draft that covers revising and rechecking the learning material based on expert validation before publishing the learning material, testing the effectiveness, and dissemination.

\section{B. Learning Material Development}

Green and Petty state that there are several criteria that materials should have [11]. The first, the materials should provide clear instructions for both teachers and students as well as teaching and learning administrators. Next, the materials should be complete to fulfill the needs of teaching and learning process. Third, the materials should function as media that connect teachers and learners. Fourth, the materials should enable leaners to learn independently to achieve the objectives being set. The last, the materials should be able to be used as the references for future development.

The principles of developing learning materials should be based on the principles of teaching and learning. It means that the principles of teaching and learning are the foundation of materials development. Olivia proposes seven principles of material development: (1) material development should be suitable with curriculum development, (2) material development should be based on theoretical development and students' needs, (3) material development is a sustainable process, (4) material development should be done systematically, (5) material development starts from simple to complex scope, (6) material development should be complete and comprehensive, and (7) the focus and orientation of material development is to help students to achieve the targeted competencies [12]. There are three main aspects in developing learning materials: (1) benefit, (2) function, and (3) objective.

Regarding the first aspect, benefit, the material development should be beneficial in teaching and learning process. In this case, the students are the ones who will take the benefits of the materials that have been developed both in terms of knowledge and skills. Going to the next aspect, the learning materials should function optimally in the teaching and learning process. It means that the materials can help the teachers, learners, and/or instructors in the teaching and learning process. Furthermore, when talking about the last aspect, objective, Susanto explains that the objectives of material development are: (1) to prepare the teaching and learning process to run optimally regardless of any possible situations, (2) to lift up teachers' motivation to manage the teaching and learning process well, and (3) to make sure that the teaching and learning process is full of updated materials, methods, and strategies [13].

Learning material development should fulfill several criteria. Regarding BIPA, there are three criteria that should be taken into account. First, the learning material development should be relevant to the expected competencies and objectives covering materials, examples, and exercises. Next, it is also essential to make sure that the learning material development is consistent, specifically related to the consistency between the materials and the objectives of the teaching and learning process. The last, the learning materials should be suitable for learners' different levels of education.

\section{The Steps of Learning Material Development}

Developing learning materials can be done by considering several steps. They are (1) determining the objectives, contents, and functions, (2) constructing the materials into a draft, (3) detailing that covers layout, parts, and any other details to get to the final draft, and (4) reviewing or validating the draft [12].

As stated above, the first step of learning material development is determining the objectives, contents, and functions. In this case, the materials are developed to fulfill BIPA teaching and learning needs. Regarding the contents, it is important to make sure that the materials, examples, and exercises are suitable for learners' competencies and levels of education. When taking into account the function, the learning materials should be useful in BIPA teaching and learning activities.

The second step is constructing the materials that have been collected into a draft. This draft is still open to revisions and additions in order to make the draft better. Particularly, the process takes place in the third step, detailing. This process covers several elements including layout, parts, and any other details needed in the learning materials. At the end of the whole process, the final draft is reviewed and validated. This can be done by asking experts to review and/or validate the final draft. In addition, asking students to try the learning material is also recommended in order to get additional opinions from the ones who will use the book. It means that the learning material development is not merely developing a product, in this case BIPA learning material, but also potentially expanded into further study to measure or test the effectiveness of the product by conducting an experiment. 


\section{Learning Material Development Components}

The contents of BIPA learning material covers (1) materials and theories about BIPA, (2) examples, (3) practices, and (4) evaluation. In line with that, Muslich explains that there are several criteria related to contents that a learning material should have [14]. The first is that the materials should be appropriate according to standard of competence and basic competence as stated in the curriculum of the subject. The second is the accuracy of the materials. The last, it is also important to have supporting materials.

Layout is one of the important components in developing learning materials. This is related to content approach that emphasizes in scholarly messages, sources, or substances [15]. In this case, the BIPA learning material, in general, is divided into three parts including opening, main, and concluding parts.

Language is undoubtedly an important component in developing learning materials. The language of instruction should be appropriate to make sure that the messages that the materials contain are delivered well. In this case, the language of instruction should cover the following aspects: (1) the language of instruction should be appropriate with learners' intellectual, social, and emotional development, (2) the language should be communicative, which means that this should be readable and grammatically appropriate, and (3) the language of instruction should be constructed cohesively and coherently between paragraphs, parts, and chapters [14]. Regarding the communicative aspect of the language of instruction, it is important to consider the learners' level of education and proficiencies. By taking this into account, the learning materials will be beneficial to help both teachers and learners to use them effectively.

The design here means the appearance of the learning materials. This aspect is essential to determine whether or not the learning materials are interesting to use. Learning materials with better appearance have greater chance to attract leaners to read and to learn from them. Muslich proposes two components related to this aspect. They are (1) illustration that provides clarity and ease to understand the contents and (2) illustration that attracts learners to read [14].

In designing the learning materials, the composition of cover, layout, and fonts are important to be considered. According to International Education Achievement, good books are those that attract learners to read, in which the design is powerful regarding this aspect [16]. The cover provides the first impression that attracts learners to open the pages. The layout and fonts provide the readability and convenience.

Physically, a good learning material can follow the format recommended by UNESCO; the minimum width of the print area is $15,5 \mathrm{~cm} \mathrm{x} 23 \mathrm{~cm}$ [17]. About the margin, Listyawan recommends to set it into $3 \mathrm{~cm}$ for the top, $3 \mathrm{~cm}$ for the left, 2 $\mathrm{cm}$ for the right, and $2 \mathrm{~cm}$ for the bottom [16]. In addition, it is also important to set the space at 1,5 [18].

The use of appropriate font is another consideration in developing learning materials. Islamiyati explains that there are two types of fonts that can be chosen: serif and sans serif [19]. However, a range of font types are also preferable as long as those are readable. Regarding the size, Listyawan recommends to set the size at $12 \mathrm{pt}$ for the contents, $14 \mathrm{pt}$ for the subheadings, and $18 \mathrm{pt}$ for the title of the chapter [16]. Furthermore, it is also essential to consider the numbering; it should be correct and consistent [20].

\section{CONCLUSION}

BIPA is a program that is specifically designed for foreigners who want to learn Bahasa Indonesia. BIPA learning at a vocational university should be appropriate with the system of the vocational education. In this case, the vocational education combines knowledge, skills, and personality aspects. Besides, it is also important to take into account the focus of vocational education that gives more portions of practicum activities.

As stated above that vocational education focuses on providing the students with more portions of practicum activities, it is essential to consider this as the basis of designing BIPA learning materials. BIPA learning materials should cover the designs of learning materials, objectives, and procedures of developing the learning materials. As a result, the design is expected to be the reference of the development of BIPA learning materials especially in vocational context.

\section{ACKNOWLEDGMENT}

The researchers would like to express deep gratitude to Politeknik Negeri Jember, especially to Pusat Penelitian dan Pengabdian Kepada Masyarakat (Politeknik Research and Devotion to Society Center) for the generous support so that the researchers were able to conduct the study. This study was funded by DIPA Politeknik Negeri Jember SP DIPA023.18.2.677607/2020, 27 December 2019. In this opportunity, the researchers would also like to express the gratitude to BIPA teachers, practitioners, and learners who joined the Darmasiswa program at Politeknik Negeri Jember, especially the Language Center of Politeknik Negeri Jember as the subject of the study.

\section{REFERENCES}

[1] Badan Pengembangan dan Pembinaan Bahasa, "Jaringan lembaga penyelenggara BIPA (Online)", 2020.

[2] I. Suyitno, "Deskripsi empiris dan model perangkat pembelajaran BIPA", Bandung: Refika Aditama, 2017.

[3] P. Nurwardani, et al., "Panduan penyusunan kurikulum pendidikan vokasi”, Jakarta: Direktorat Jenderal Pembelajaran dan Kemahasiswaan Kementerian Riset Teknologi dan Pendidikan Tinggi, 2016.

[4] Departemen Pendidikan Nasional, "Sosialisasi KTSP: Pengembangan bahan ajar", Jakarta: Departemen Pendidikan Nasional, 2008.

[5] L. W. Anderson, and D. R. Krathwohl, "Taxonomy for learning teaching and assesing: a revision of bloom's taxonomy of educational objectives", New York: Longman, 2009.

[6] L. D. Fink, "A self-directed guide to designing course for significant learning”, San Francisco: Jossey-Bass, 2003.

[7] B. Bixler, "The ABCDs of writing instructional objectives (Online)", 2011.

[8] B. Murray, "Learning taxonomy-Krathwohl's affective domain (Online)", 2014.

[9] J. D. Brown, "The elements of languange curriculum: a systematic approach to program development”, Boston: Heinle Publisher, 1995.

[10] J. C. Richards, "Curriculum development in languange teaching", Cambrdge: Cambridge University Press, 2001.

[11] S. Akbar, "Instrumen perangkat pembelajaran", Bandung: PT Rosda Karya, 2015.

[12] D. Widyartono, "Pengembangan bahan ajar matakuliah Bahasa Indonesia berbasis web interaktif", Malang: Program Pascasarjana Universitas Negeri Malang, 2010. 
[13] J. Mbulu, and Suhartono, "Pengembangan bahan ajar: Konsep-konsep dasar pengembangan bahan ajar", Malang: Universtitas Negeri Malang, 2004.

[14] G. Susanto, "Bahan ajar BIPA tingkat pemula untuk pebelajar Jepang", Malang: Program Pascasarjana Universitas Negeri Malang, 2008.

[15] M. Muslich, "Text book writing: Dasar-dasar pemahaman, penulisan, dan pemakaian buku teks", Yogyakarta: Ar-Ruzz Media Group, 2010.

[16] Sitepu, "Penulisan buku teks pelajaran", Bandung: PT Remaja Rosdakarya, 2012.
[17] W. Listyawan, "Jurnal belajar 8 PBB: Analisis buku ajar (Online)", 2014.

[18] B. Legowo, "Bahan ajar: Satu ukuran profesionalisme dosen dalam proses pembelajaran (Online)", 2011

[19] Fitri, "Ragam dan kriteria buku (Online)", 2011.

[20] N. Islamiyati, "Font terbaik untuk media cetak, online, dan email (Online)", 2014.

[21] R.P. Afnita, et al., "Aspek-aspek bahan ajar (Online)", 2012. 